\title{
The Impact of Gender and Years of Teaching Experience on College Teachers' Digital Competence: An Empirical Study on Teachers in Gansu Agricultural University
}

\author{
Yu Zhao ${ }^{1, *}$, Ana María Pinto Llorente ${ }^{1} \mathbb{1}$, María Cruz Sánchez Gómez ${ }^{1} \mathbb{D}$ and Liping Zhao ${ }^{2}$ \\ 1 Faculty of Education, University of Salamanca, 37008 Salamanca, Spain; ampintoll@usal.es (A.M.P.L.); \\ mcsago@usal.es (M.C.S.G.) \\ 2 Faculty of Humanities, Gansu Agricultural University, Lanzhou 730070, China; zhaolp@gsau.edu.cn \\ * Correspondence: zhaoy426@yahoo.com
}

check for

updates

Citation: Zhao, Y.; Pinto Llorente, A.M.; Sánchez Gómez, M.C.; Zhao, L. The Impact of Gender and Years of Teaching Experience on College Teachers' Digital Competence: An Empirical Study on Teachers in Gansu Agricultural University. Sustainability 2021, 13, 4163. https:// doi.org/10.3390/su13084163

Academic Editor: Michele Biasutti

Received: 12 March 2021

Accepted: 6 April 2021

Published: 8 April 2021

Publisher's Note: MDPI stays neutral with regard to jurisdictional claims in published maps and institutional affiliations.

Copyright: (c) 2021 by the authors. Licensee MDPI, Basel, Switzerland. This article is an open access article distributed under the terms and conditions of the Creative Commons Attribution (CC BY) license (https:/ / creativecommons.org/licenses/by/ $4.0 /)$.

\begin{abstract}
With the development of Information and Communication Technologies (ICT) and the emergence of the Corona virus (COVID-19,) our way of life and even our education have been affected. The education approach has changed from traditional tutorials to online education. As a result, it has been a necessary for not only students but also teachers to improve their digital competence. The aim of this study was to describe in-service teachers' self-perceptions of digital competence in the context of higher education and analyze the impact of gender and years of teaching experience on college teachers' digital competence. For this purpose, a quantitative methodology has been used. A sample of 536 in-service teachers from Gansu Agricultural University, China, completed a questionnaire on digital competence. The data were collected in the academic year of 2019-2020. The results show that the sample considered themselves positively in information and data literacy, communication and collaboration, security and problem solving, while they self-evaluated their digital content creation negatively. Regarding the variables studied, significant differences were found in favor of male college teachers in the perception of digital competence. In relation to the teaching experience, teachers with less teaching experience thought themselves better in the areas of communication and collaboration, digital content creation, security and problem solving.
\end{abstract}

Keywords: digital competence; gender; years of teaching experience; higher education; China

\section{Introduction}

Nowadays, we are in an information and knowledge society, which originated from profound changes in the construction of knowledge and learning, and is characterized by its complexity and its increasing globalization, and its use of Information and Communication Technologies (ICT) [1]. The rising pace of technological change and the characteristics of ICT itself have led to important and significant changes in many areas, and the use of ICT continues to grow in the field of education.

The integration of emerging technologies into the educational environment and daily life has promised a boom of digital media and e-learning environments in which educational resources with open access and learning objects express their optimal educational potential [2]. Some of the features of the tremendous transformative potential offered by these technologies are the possibility to store and rapidly transmit information, the disappearance of space and time barriers and the use of multiple media formats. Within this technological context, it is crucial to be able to operate successfully in the digital domain or to develop digital related competence [3].

Moreover, since the whole world is suffering from the COVID-19 pandemic, many institutions and organizations are changing the way they teach and seek to provide a convenient, safe and flexible educational environment for their students. The COVID-19 crisis has indeed brought different changes and tensions to the education system, and a 
fast and strong transition has been brought to distance training with technical support [3] In such a context, the weak points of teacher training have emerged. Teachers perceived a higher workload during the lockdown along with negative emotions because of their shortcomings in digital competence-related formation [4]. Teachers, as an indispensable role in educational activities, should improve their digital competence accordingly. In addition to upgrading their teaching content, they should also attach great importance to tailoring their teaching methods to meet these new challenges; they need to enhance their abilities to adapt to the current situation and to improve the quality of education $[5,6]$.

Over the past several years, several studies have analyzed digital competence level in the field of education in different contexts [7-10]. Some studies have focused on factors that could influence digital competence [11-14]. Other studies have explored the pedagogical approaches involved in digital competence $[15,16]$. Many of the studies have been conducted with students; to accompany young learners in the development of competence, to guarantee optimal implementation of technological tools and to promote improvements in the quality of education, it is necessary that teachers are, in turn, capable.

Our study focused on the level of digital competence of university in-service teachers as well as the impact of variables such as gender and teaching experience upon digital competence. The goals of our study are:

1. To describe in-service teachers' self-perceptions of digital competence in the context of higher education.

2. To analyze whether their self-perception of digital competence varies with variables like gender and age.

\section{Theoretical Framework: Digital Competence}

With the advancement of technology, the ability to deal with technological tools in everyday life is in the spotlight, especially with the outbreak of the COVID-19 pandemic and its huge impact on the educational industry, and digital competence has become today's hot topic.

The concept of digital competence has been frequently addressed and raised by scholars and policy-related discussions. It has been identified as one of the eight key life skills in the recommendation on key competences for lifelong learning that is proposed by European Commission, understood as follows [17]:

“. .. the set of knowledge, skills, attitudes, abilities, strategies, and awareness that are required when using ICT and digital media to perform tasks; solve problems; communicate; manage information; collaborate; create and share content; and build knowledge effectively, efficiently, appropriately, critically, creatively, autonomously, flexibly, ethically, reflectively for work, leisure, participation, learning, socializing, consuming and empowerment" [18] (p. 30).

Digital competence takes the form of cognitive, attitudinal, and technical skills that help to mitigate and solve numerous problems and challenges in the knowledge society [19]. Moreover, digital competence includes issues related to technology, information, multimedia, and communication that encourage critical, responsible, and creative use of technology, which are essential to the learning process and participation in the 21st century [9].

After the European Commission considered digital competence as one of the eight key life skills, they developed DigComp (European Digital Competence Framework) as a reference framework to explain the meaning of "digital competence", and there are updated versions of DigComp according to the development of society. The report known as DigComp 2.0 presented an updated list of 21 capabilities from five competence areas (Table 1): (1) information and data literacy; (2) communication and collaboration; (3) digital content creation; (4) safety; and (5) problem solving [20-22]. In 2017, this framework was updated into DigComp 2.1, in which eight capability levels and examples of use can be found [20]. With these categories, specific sub-competencies can be assessed at different 
levels of proficiency and it can help set learning goals, identify training opportunities and facilitate job searches.

Table 1. The digital competence framework for citizens [20].

\section{Information and data literacy}

2. Communication and collaboration

. Digital content creation

4. Safety

5. Problem solving
1.1 Browsing, searching, filtering data, information and digital content

1.2 Evaluating data, information and digital content 1.3 Managing data, information and digital content

2.1 Interacting through digital technologies

2.2 Sharing through digital technologies

2.3 Engaging in citizenship through digital technologies

2.4 Collaborating through digital technologies

2.5 Netiquette

2.6 Managing digital identity

3.1 Developing digital content

3.2 Integrating and re-elaborating digital content

3.3 Copyright and licenses

3.4 Programming

4.1 Protecting devices

4.2 Protecting personal data and privacy

4.3 Protecting health and well-being

4.4 Protecting the environment

5.1 Solving technical problems

5.2 Identifying needs and technological responses

5.3 Creatively using digital technologies

5.4 Identifying digital competence gaps

The basis for effective teaching and learning with ICT comes from the interaction between content, pedagogy and technical knowledge (T-PACK) [23]. Considering teachers as the principal dominant performers in the digital learning environment, teachers' digital competence can be understood as "the use of ICT with a good pedagogical-didactic ICT understanding and to be aware of how this might impact the learning strategies and educational formation of pupils" [24] (p. 68).

In 2017, the Joint Research Centre (JRC) published the European Digital Competence Framework for Educators: DigCompEdu. In the DigCompEdu project, digital competence is considered as the ability of users to make safe, critical and creative use of ICT to satisfy different objectives [25]. It established a model of digital competence for trainers [26]. Additionally, Redecker [27] categorized an educator's digital competence into six areas: (1) professional engagement, (2) digital resources, (3) teaching and learning, (4) assessment, (5) empowering learners, and (6) facilitating the digital competence of the learners [28]. Teacher Digital Competence (TDC) was presented following the main skills of digital competence and it can be defined as the set of knowledge, skills and attitudes needed to be functional in a digital teaching environment [29].

Moreover, the Spanish National Institute for Educational Technology and Teacher Training (INTEF), in collaboration with other institutions, has developed and expanded an educational initiative since 2012 and launched a document called the Common Digital Competency Framework for Teachers (CDCFT), which provides a descriptive reference for relevant educational institutions, sectors and educators that can be used for training purposes, assessment, certification and accreditation processes; adapted from DigComp and DigCompEdu, the framework is highly comprehensive and is also divided into five competence areas (information and data literacy, communication and collaboration, digital content creation, safety and problem solving) including 21 competences. These are competences that teachers need to develop for improved educational practice and continuous professional development in the 21st century, and a new revised version was launched in 2017 [30]. 
The policies and documents launched by countries show the importance of technology and digital-related capabilities. In China, the General Office of the Central Committee of the Communist Party of China and the General Office of the State Council [31] and the Chinese Ministry of Education [32] have released several plans and blue papers on digitization and informatization, covering the economy, education and other industries, considering digital competence as a part of the lifelong learning process [33]. China is one of the largest technology and knowledge exporting countries among the eastern countries, and it has a large population. However, compared with developed countries, the development of digital competence in China and China's education informatization is still at an initial step and it is still in the process of exploring the establishment of China's digital competence framework; meanwhile, there has been a comprehensive evaluation system in the European countries. People's digital ability in China is uneven, which is highlighted as the international information gap and the domestic information gap. The domestic information gap is also reflected between regions and groups of people [34]. As an underdeveloped region in China, the differences are more obvious in western China. In the 13th Five-Year Plan of Education Informatization, it is emphasized that the evaluation index system and assessment methods for regions, schools, curricula, resources, educators and students' informatization level should be developed, which provides the development direction and policy basis for the introduction of China's digital literacy framework [35].

\section{Materials and Methods}

The purpose of this study is to describe in-service teachers' self-perceptions of digital competence in the context of higher education and analyze the impact of gender and age on their self-perception of digital competence. With established research goals, this study used a quantitative non-experimental, descriptive and inferential methodology [36]. The data were collected through an online questionnaire.

\subsection{Sample}

The collection of data was targeted at all of the teachers who were working at Gansu Agricultural University, which is located in the western part of China.

The final sample of this study consisted of 536 in-service teachers from 22 faculties of Gansu Agricultural University in China, which was a representative sample. A total of $61.2 \%(n=328)$ of the sample were female and $38.8 \%(n=208)$ were male, ranging in age from 23 to 68 .

\subsection{Instrument Used to Collect Information}

The survey instrument used in this study was adapted from a seminal questionnaire designed for teaching staff in higher education by Taquez, Rengifo and Mejía [37] and a tool for self-diagnosis of digital competences from López [38]. The questionnaire was originally written in Spanish and was translated into Chinese for the research participants. A draft was made including all the items considered necessary to carry out the research. The validity of the instrument was analyzed from two perspectives: content validity, through rational analysis by a panel of judges, and empirical validity, through an exploratory factorial analysis. With the collaboration of experts in the field of research methodology and education, the characteristics and external validity were checked. To finish this phase, the contributions of the experts were analyzed and changes were made to the instrument. We measured the Cronbach's alpha to know the internal consistency of the surveys. The questionnaire had an internal consistency of $\alpha=0.974$. The alpha coefficient of this survey suggested that the items had relatively high internal consistency.

This questionnaire included 56 items and was divided into four sections (Table 2): Identification (data to identify the respondents), teachers' self-perception in digital competence, the use of ICT tools, and the teachers' attitude and opinion concerning using ICT tools in the teaching process. The items are made up of closed-ended, multiple choice, open-ended and Likert-type ordinal scale questions. 
Table 2. Sections of the questionnaire. ICT: Information and Communication Technologies.

\begin{tabular}{cl}
\hline \multirow{2}{*}{ Identification } & $\begin{array}{l}\text { Age; gender; teaching experience; faculty; } \\
\text { mentor situation; number of classes you teach; } \\
\text { type of classes you teach; type of training about } \\
\text { ICT, how digital competence training was } \\
\text { acquired and motivation for using ICT tools. }\end{array}$ \\
\hline \multirow{2}{*}{ Teachers' self-perception in digital competence } & $\begin{array}{l}\text { Information and data literacy; communication } \\
\text { and collaboration; digital content creation; } \\
\text { safety and problem solving. }\end{array}$ \\
\hline Use of ICT tools & $\begin{array}{c}\text { Use of ICT tools, frequency of using ICT tools. } \\
\text { Attitude }\end{array}$ \\
\hline $\begin{array}{l}\text { Attitude in using ICT tools in the } \\
\text { teaching process. }\end{array}$ \\
\hline
\end{tabular}

\subsection{Procedure of Data Collection and Analysis}

The questionnaires were prepared using Qualtrics and were shared with the in-service teachers through QR codes and links. The anonymity of the data was ensured. The data were collected in the academic year 2019-2020 in Gansu Agricultural University in China.

The statistical analysis of the data was performed with Statistical Package for the Social Sciences (SPSS v.22) software. We performed a univariate descriptive analysis, calculating the mean and the standard deviation. Data were also processed by inferential analysis. Once the parametric assumptions of normality and homoscedasticity had been checked, we chose to use the non-parametric Mann-Whitney $U$ test for the dual variable of gender and the non-parametric Kruskal-Wallis test for the variable of teaching experience.

\section{Results}

Due to the volume of data obtained in the complete study, this paper only presents data from the second section: Self-perception of teachers' digital competence.

In this section of our paper, we present the results obtained with the descriptive analysis of data, and the results obtained with the inferential analysis. These results focus on the teachers' self-perception in terms of their digital competence.

\subsection{Descriptive Analysis}

The following are the results obtained from the teachers when answering the second section of the questionnaire; composed of 28 items, it evaluates the respondent's perception of digital competence, and is divided into the following competence areas: information and data literacy (four items), communication (10 items), content creation (five items), security (five items) and problem solving (four items). Participants responded, as explained above, in a Likert-type rating scale from 1 to 4 trying to avoid deviations.

Table 3 shows the descriptive statistical results of the teachers' self-perception in digital competence in terms of information and data literacy.

Table 3. Descriptive statistical results regarding teachers' self-perception of digital competence in information and data literacy.

\begin{tabular}{|c|c|c|c|c|c|c|}
\hline Information and Data Literacy & Mean & SD & $\begin{array}{l}\text { Very } \\
\text { Bad }\end{array}$ & Bad & Good & $\begin{array}{l}\text { Very } \\
\text { Good }\end{array}$ \\
\hline I find interesting sources of information for the teaching. & 2.88 & 0.634 & 3.0 & 17.9 & 67.4 & 11.8 \\
\hline $\begin{array}{l}\text { I am aware of the restrictions of published copyrighted } \\
\text { educational resources. }\end{array}$ & 3.05 & 0.665 & 2.1 & 13.6 & 61.8 & 22.6 \\
\hline $\begin{array}{l}\text { I evaluate the quality of the online educational resources for } \\
\text { accuracy and consistency with the curriculum. }\end{array}$ & 2.88 & 0.649 & 3.0 & 19.2 & 57.1 & 20.7 \\
\hline I use social media to organize resources for teaching purposes. & 2.96 & 0.719 & 3.0 & 16.8 & 65.5 & 14.7 \\
\hline
\end{tabular}


Teachers perceived themselves to be good at handling information and data literacy. Most of them rated themselves as good in finding sources of information $(67.4 \%$, $n=361$ ). When they were asked about copyright, evaluation of resource quality and the use of social media to organize resources in accordance to their teaching purpose, more than half of them considered themselves as good $(61.8 \% n=331,57.1 \% n=305$, and $65.5 \% n=351$, respectively).

With regard to teachers' self-perception in digital competence in communication (Table 4), more than 50 percent believed that they were good at interacting, sharing and collaborating through digital technologies as the means were all over 2.5. When teachers were asked whether they communicated with their students through digital means, $65.5 \%$ $(n=349)$ considered they did a good job, and $14.7 \%(n=9)$ rated themselves as very good. Similar results were obtained when they assessed their content and educational resources selection: $62.3 \%(n=334)$ thought they were good at it, while $20.5 \%(n=110)$ believed they were very good in selecting content and educational resources found in different social media and virtual communities.

Table 4. Descriptive statistical results about teachers' self-perception of digital competence in communication and collaboration.

\begin{tabular}{|c|c|c|c|c|c|c|}
\hline Communication and Collaboration & Mean & SD & Very Bad & Bad & Good & Very Good \\
\hline $\begin{array}{l}\text { I create digital work environments to communicate with } \\
\text { my students. }\end{array}$ & 2.92 & 0.655 & 3.0 & 16.8 & 65.5 & 14.7 \\
\hline $\begin{array}{l}\text { I organize interaction activities through digital tools and share } \\
\text { these activities with information accompanied by images, } \\
\text { links and videos. }\end{array}$ & 3.00 & 0.670 & 1.5 & 17.9 & 59.7 & 20.9 \\
\hline $\begin{array}{l}\text { I select educational contents and resources that are found in } \\
\text { different social media and virtual communities. }\end{array}$ & 3.02 & 0.641 & 1.1 & 16.0 & 62.3 & 20.5 \\
\hline $\begin{array}{l}\text { I identify digital services according to their } \\
\text { educational usefulness. }\end{array}$ & 2.86 & 0.683 & 2.6 & 23.5 & 59.3 & 14.6 \\
\hline $\begin{array}{l}\text { I participate in virtual communities and social networks } \\
\text { actively for the purpose of updating and achieving } \\
\text { professional development. }\end{array}$ & 2.72 & 0.736 & 4.7 & 30.8 & 52.2 & 12.3 \\
\hline
\end{tabular}

Regarding teachers' self-perception in terms of digital competence in digital content creation, the results obtained (Table 5) show that teachers were less confident in creating digital content. When they were asked about whether they could recreate digital content and license it properly, $46.8 \%(n=251)$ of them thought they were good and $9.5 \%(n=51)$ rated themselves as excellent. Of the 536 teachers, $255(47.6 \%)$ stated that they knew well the regulations applicable to the online use of educational materials while $6.7 \%(n=36)$ thought they were very good. Additionally, less than half of teachers thought they were good at creating websites for students $(33.0 \%, n=177)$, reusing digital content from virtual communities $(39 \%, n=209)$ and modifying the advanced functions of digital tools in relation to the needs of teachers' work $(41.2 \%, n=221)$.

In relation to teachers' self-perception in terms of digital competence in security (Table 6), the majority of the participants self-assessed their level between good $(69.6 \%$, $n=373)$ and very good $(16.2 \%, n=87)$. Similar results were obtained when teachers were asked if they could maintain an active attitude in the management and protection of digital identity, where $61.2 \%(n=328)$ considered they were good and $6.2 \%(n=33)$ very good. In the case of private data and the prevention of social and psychological conflict situations in the use of digital tools, the main results were between good $(59.7 \% n=320,58.8 \% n=315)$ and very good $(14.9 \% n=80,10.1 \% n=54)$. The data analysis also led to results that showed that teachers self-assessed themselves as good at updating and protecting their devices $(49.4 \%, n=264)$. 
Table 5. Descriptive statistical results about teachers' self-perception of digital competence in digital content creation.

\begin{tabular}{|c|c|c|c|c|c|c|}
\hline Digital Content Creation & Mean & SD & Very Bad & Bad & Good & Very Good \\
\hline $\begin{array}{l}\text { I create websites where multimedia educational contents } \\
\text { adapted to the learning needs of students are published. }\end{array}$ & 2.23 & 0.807 & 19.2 & 43.3 & 33.0 & 4.5 \\
\hline $\begin{array}{l}\text { I rework digital sources and turn them into new and creative } \\
\text { digital content, and I can license them appropriately. }\end{array}$ & 2.58 & 0.767 & 7.6 & 36.0 & 46.8 & 9.5 \\
\hline $\begin{array}{l}\text { I reuse the digital content of virtual teaching } \\
\text { communities creatively. }\end{array}$ & 2.41 & 0.761 & 10.4 & 44.2 & 39.0 & 6.3 \\
\hline $\begin{array}{l}\text { I know the regulations that apply to the use of online } \\
\text { educational materials and I know how to license my own } \\
\text { digital production. }\end{array}$ & 2.50 & 0.781 & 11.2 & 34.5 & 47.6 & 6.7 \\
\hline $\begin{array}{l}\text { I tailor the advanced features of digital media to students' } \\
\text { personal learning styles and interests. }\end{array}$ & 2.49 & 0.799 & 10.3 & 39.4 & 41.2 & 9.1 \\
\hline
\end{tabular}

Table 6. Descriptive statistical results about teachers' self-perception of digital competence in security.

\begin{tabular}{lcccccc}
\hline \multicolumn{1}{c}{ Security } & Mean & SD & Very Bad & Bad & Good & Very Good \\
\hline I update and protect my devices frequently. & 2.65 & 0.757 & 6.3 & 33.4 & 49.4 & 10.8 \\
\hline I know how my private data are collected and used. & 2.87 & 0.682 & 2.6 & 22.8 & 59.7 & 14.9 \\
\hline $\begin{array}{l}\text { I maintain an active attitude in managing and protecting my } \\
\text { own digital identity and that of my students. }\end{array}$ & 2.90 & 0.701 & 3.7 & 18.8 & 61.2 & 6.2 \\
\hline $\begin{array}{l}\text { I know and I can apply prevention protocols for social and } \\
\text { psychological conflict situations in the use of digital media. }\end{array}$ & 2.74 & 0.704 & 5.0 & 26.1 & 58.8 & 10.1 \\
\hline $\begin{array}{l}\text { I know the positive and negative effects of the use of } \\
\text { technology on the environment. }\end{array}$ & 3.00 & 0.601 & 1.9 & \multirow{2}{*}{12.3} & 69.6 & \multirow{2}{*}{16.2} \\
\hline
\end{tabular}

In-service teachers were asked about their self-perception in terms of problem solving (Table 7). Regarding resolving simple technical problems, more than 50 percent thought they were good $(63.1 \% n=338)$. Similar results were obtained when teachers were asked whether they could choose the right tools to accomplish tasks evaluating different digital environments, as $56.5 \%(n=303)$ thought they were good, and $8.0 \%(n=43)$ very good. Moreover, the majority of these teachers considered they were good in using various technologies to analyze their everyday job needs $(55.8 \% n=299)$, and in using emerging digital technologies to fill gaps in teaching and professional development $(57.5 \%, n=308)$.

Table 7. Descriptive statistical results about teachers' self-perception of digital competence in problem solving.

\begin{tabular}{|c|c|c|c|c|c|c|}
\hline Problem Solving & Mean & SD & Very Bad & Bad & Good & Very Good \\
\hline $\begin{array}{l}\text { I can solve non-complex technical problems with the help of a } \\
\text { manual or available technical information. }\end{array}$ & 2.82 & 0.667 & 3.5 & 22.0 & 63.1 & 11.4 \\
\hline $\begin{array}{l}\text { I can critically evaluate the different possibilities that digital } \\
\text { environments, digital tools and digital services could provide } \\
\text { to solve teaching work related tasks. }\end{array}$ & 2.68 & 0.676 & 3.9 & 32.1 & 56.0 & 8.0 \\
\hline $\begin{array}{l}\text { I can use technologies to analyze my daily work needs and } \\
\text { manage innovative solutions. }\end{array}$ & 2.68 & 0.680 & 4.1 & 22.1 & 55.8 & 8.0 \\
\hline $\begin{array}{l}\text { I try to use emerging digital technologies to help me keep up } \\
\text { with the times and to fill possible gaps in the digital } \\
\text { competence that I need for my teaching and } \\
\text { professional development. }\end{array}$ & 2.72 & 0.683 & 3.9 & 29.3 & 57.5 & 9.3 \\
\hline
\end{tabular}




\subsection{Inferential Analysis}

In this section, the results of the comparison of mean values according to the variables of gender and teaching experience are presented, and the significant differences found in this inferential analysis will be discussed in a detailed way.

\subsubsection{Gender}

According to the Mann-Whitney $U$ test (Table 8), the results showed significant differences in five dimensions in teachers' self-perception in digital competence $(p<0.05)$. Moreover, the results indicated that men always rated themselves higher than women in digital competence in information, communication, digital content creation, security and problem solving by comparing the mean of their selection results in different dimensions.

Table 8. Mann-Whitney $U$ test with regard to the gender variable.

\begin{tabular}{|c|c|c|c|c|c|c|c|}
\hline \multirow{3}{*}{ Dimensions } & \multicolumn{7}{|c|}{ Gender } \\
\hline & \multirow[t]{2}{*}{$\mathbf{U}$} & \multirow[t]{2}{*}{$\mathbf{Z}$} & \multirow[t]{2}{*}{$\mathbf{P}$} & \multicolumn{2}{|c|}{ Men } & \multicolumn{2}{|c|}{ Women } \\
\hline & & & & Mean & SD & Mean & SD \\
\hline Information & $30,461.000$ & 2.142 & 0.032 & 3.01 & 0.531 & 2.90 & 0.513 \\
\hline Communication & $26,882.500$ & 4.157 & 0.000 & 2.93 & 0.473 & 2.76 & 0.506 \\
\hline Creation & $25,589.000$ & 4.912 & 0.000 & 2.63 & 0.654 & 2.32 & 0.620 \\
\hline Security & $23,794.500$ & 6.007 & 0.000 & 3.00 & 0.547 & 2.72 & 0.554 \\
\hline Solve problem & $23,627.500$ & 6.146 & 0.000 & 2.91 & 0.531 & 2.61 & 0.584 \\
\hline
\end{tabular}

\subsubsection{Teaching Experience}

Overall, among the 536 teachers, there were $26 \%(n=13)$ who had a teaching experience of less than five years, $20 \%(n=106)$ of them had five to nine years of teaching experience, $33 \%(n=177)$ have worked 10 to 19 years as a teacher, $16 \%(n=86)$ of them had a teaching experience of 20 to 29 years, and there were $5 \%(n=29)$ who had been a teacher for more than 30 years.

In relation to teachers' perception of digital competence in information and data literacy, the results indicated that there were no obvious differences among teachers with different teaching experience (Figure 1, Table 8). However, teachers with five to nine years teaching experience rated themselves as good $(x=3.03)$.

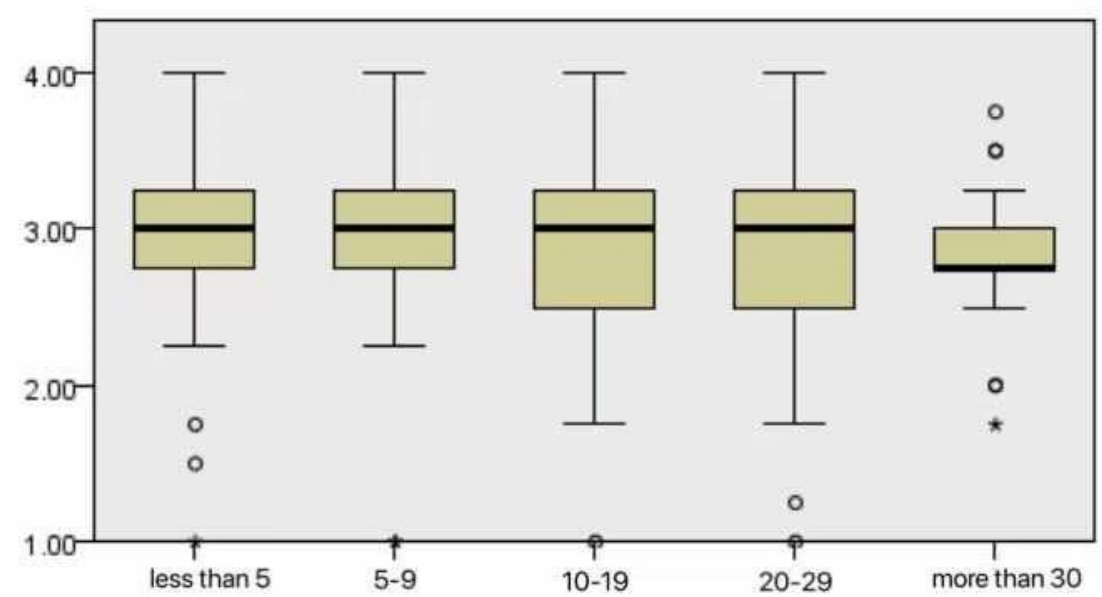

Figure 1. Mean values in information and data literacy divided by teaching experience.

With regard to communication and collaboration, teachers with less teaching experience considered themselves as more capable in communicating and collaborating (Figure 2, Table 8). 


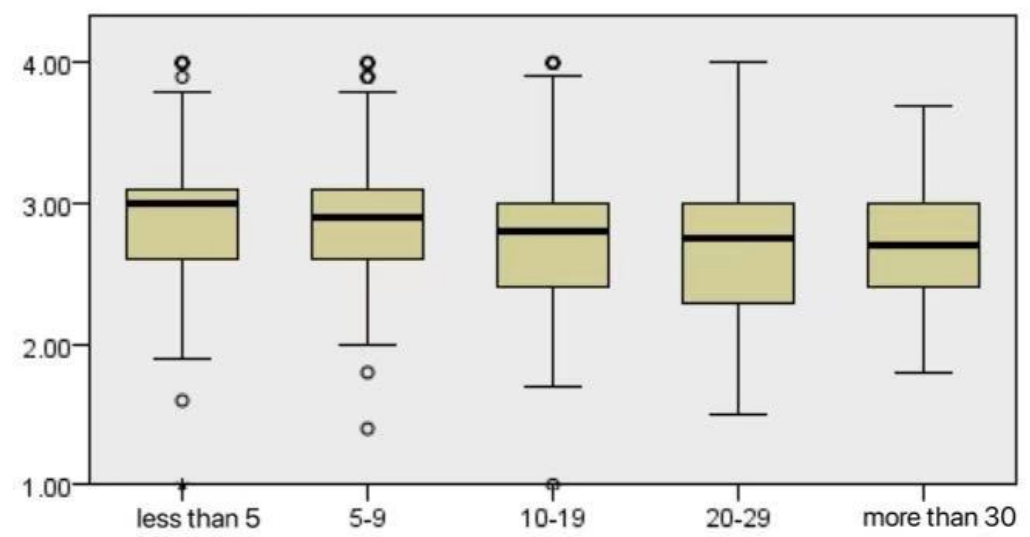

Figure 2. Mean values in communication and collaboration divided by teaching experience.

In relation to teachers' self perception in digital content creation, the scores were higher for teachers who had less than five years of teaching experience, while those with over 30 years' teaching experience thought they were not as good in creating digital content (Figure 3, Table 8).

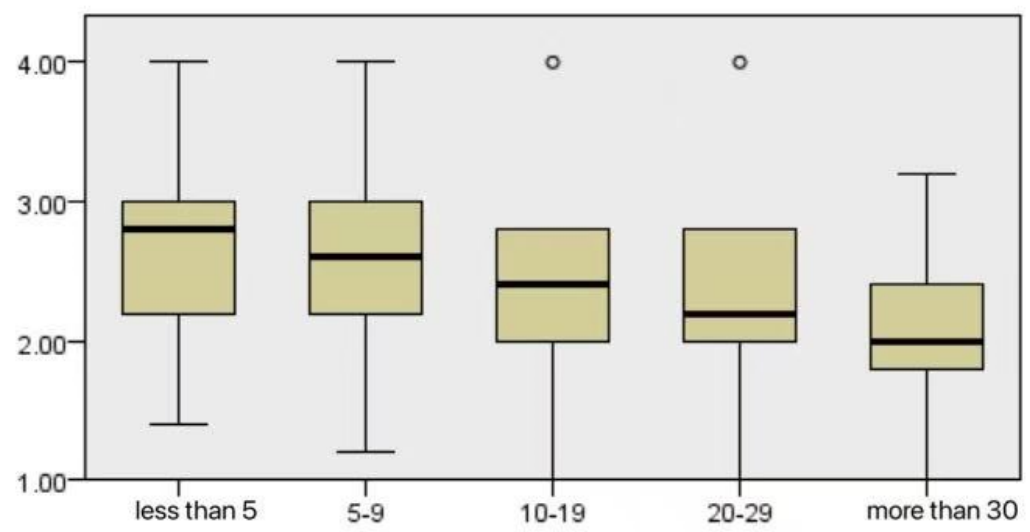

Figure 3. Mean values in digital content creation divided by teaching experience.

When teachers with different teaching experience were asked about their perceptions in terms of digital competence in security, teachers with less teaching experience rated themselves better (Figure 4, Table 8). When asked about their perception in terms of digital competence in solving problems with ICT tools, similar results were obtained (Figure 5, Table 8).

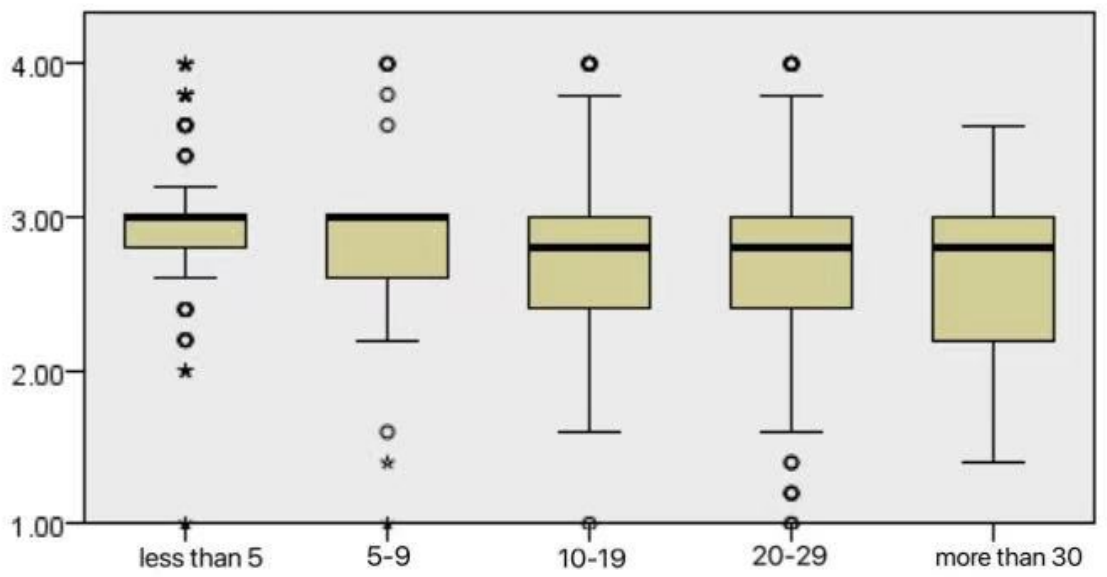

Figure 4. Mean values in security, divided by teaching experience. 


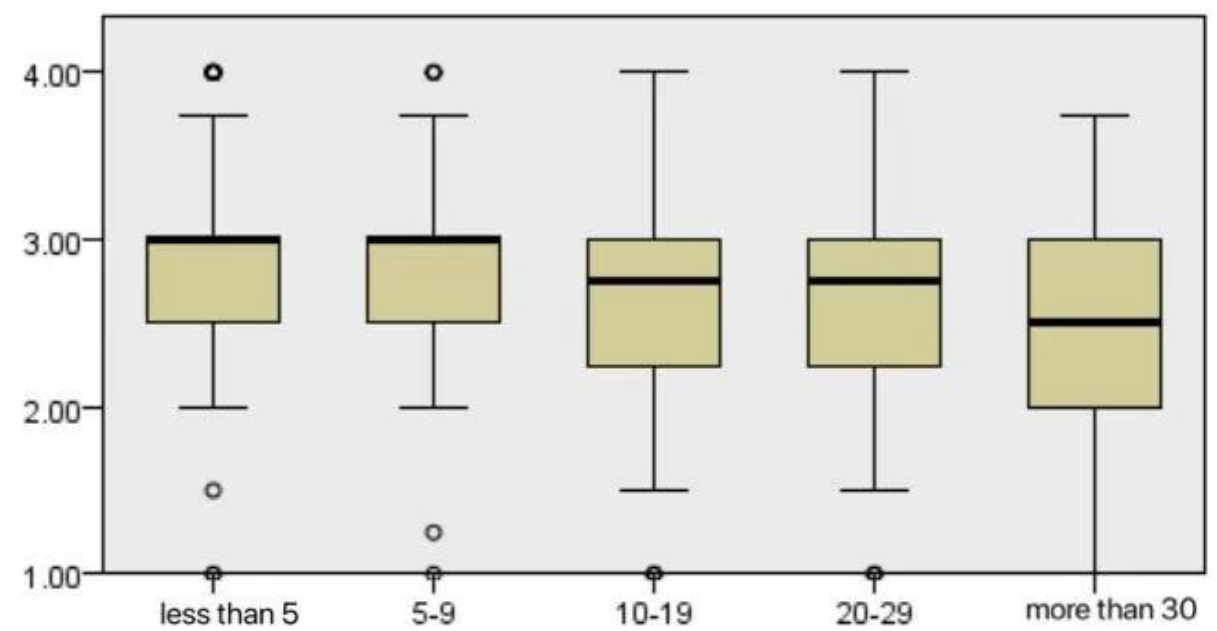

Figure 5. Mean values in problem solving, divided by teaching experience.

Teaching experience was considered as a differentiating variable, according to the results of the Kruskal-Wallis test (Table 9). There was no significant difference in the area of information and data literacy $(p>0.05)$. Meanwhile, there were significant differences among areas in communication and collaboration, digital content creation, security and problem solving $(p<0.05)$.

Table 9. Kruskal-Wallis test divided by teaching experience.

\begin{tabular}{|c|c|c|c|c|c|c|c|c|c|c|c|}
\hline \multirow{3}{*}{ Dimensions } & \multicolumn{11}{|c|}{ Teaching Experience } \\
\hline & \multirow{2}{*}{ P. } & \multicolumn{2}{|c|}{ Less than 5 Years } & \multicolumn{2}{|c|}{ 5-9 Years } & \multicolumn{2}{|c|}{ 10-19 Years } & \multicolumn{2}{|c|}{ 20-29 Years } & \multicolumn{2}{|c|}{ More than 30 Years } \\
\hline & & Mean & SD & Mean & SD & Mean & SD & Mean & SD & Mean & SD \\
\hline $\begin{array}{l}\text { Information and } \\
\text { data literacy }\end{array}$ & 0.084 & 2.94 & 0.485 & 3.03 & 0.509 & 2.92 & 0.555 & 2.91 & 0.549 & 2.83 & 0.444 \\
\hline $\begin{array}{l}\text { Communication } \\
\text { and collaboration }\end{array}$ & 0.000 & 2.93 & 0.465 & 2.92 & 0.508 & 0.2 .75 & 0.495 & 2.74 & 0.524 & 2.69 & 0.466 \\
\hline Digital content creation & 0.000 & 2.66 & 0.620 & 2.56 & 0.642 & 2.35 & 0.678 & 2.26 & 0.679 & 2.06 & 0.610 \\
\hline Security & 0.001 & 2.97 & 0.500 & 2.87 & 0.487 & 2.79 & 0.557 & 2.72 & 0.718 & 2.63 & 0.578 \\
\hline Problem solving & 0.001 & 2.88 & 0.551 & 2.82 & 0.522 & 2.65 & 0.564 & 2.62 & 0.657 & 2.44 & 0.607 \\
\hline
\end{tabular}

\section{Discussion}

Modern digitalization implies an increasingly complex school environment [39]. As ICT tools are becoming a central part of everyday work, teachers have to rethink and change their previous educational methods through technology. At this point, the teacher's digital competence has become an essential part of the educational process.

This study described in-service teachers' perceptions of digital competence in the context of higher education and attempts to outline the variables of gender and teaching experience. An instrument to demonstrate validity and reliability content was used to reach study objectives.

This study identified the teachers' perception of digital competence by performing a descriptive analysis that enabled us to know how teachers thought about their digital competence. In general, their perception of digital competence was positive. If we focus on the dimensions analyzed in the study, across the five dimensions of digital competence, teachers perceived themselves as performing well in the areas of information and data literacy, communication and collaboration, and security and problem solving; more than half of the in-service teachers self-rated themselves as "good" or "very good". Their selfperceptions of information and data literacy, communication and collaboration and security were quite high. Most of the in-service teachers considered that they are capable of solving problems related to using ICT tools in their routines. However, their confidence in digital 
content creation was low: $43.3 \%$ of in-service teachers thought they were bad at creating internet spaces for public educational resources and $44.2 \%$ of them thought they were bad at creating digital content. This shows that teachers consider ICT tools as a minimum support tool but they do not feel capable to create their own digital content and share it with other users [40]. Similar results can be found on this topic [41-43].

Some significant differences were observed regarding the effects of the gender and teaching experience variables on the five dimensions of digital competence.

There are several studies that have investigated the impact of gender on digital competence. Some studies have revealed the significance difference between the gender $[11,13,38,44,45]$. There are also studies that have not observed any differences between genders [46]. The results in this study show that men rated themselves higher than women in teachers' perceptions of digital competence, and there was significant difference in the areas of communication and collaboration, digital content creation, security and problem solving. Similar results were obtained in the studies of Cabezas and Casillas [11], González, Martín, Sanchez-Ferreira and Diogo [13] and López, Pozo and Fuentes [38]. The public perception is that men have higher scores in their self-perception of digital competence. However, many novel findings about gender stereotypes associated with the use of ICT tools and digital competence are provided. Moreno-guerrero, Fernandez Mora and Alonso Garcias [45] indicated that women rate themselves better than men in some areas, such as storage and retrieval of data and digital content, and Garcia Gonzalez, Gros, and Escofet [47] found that women in the context of higher education consider themselves to be very competent in the informal use of ICTs, choosing more academic and informational uses, and oriented to more engaging and communicative pedagogy. With the results obtained in this study, we can provide a gender perspective from the standpoint of Asian university in-service teachers.

In relation to the variable of teaching experience, many studies have analyzed age as a variable $[13,48,49]$. However, only a few studies have explored the relationship between teaching experience and digital competence [50,51]. In this study, we observed a significant difference among teachers with different lengths of teaching experience in the areas of communication and collaboration, digital content creation, security and problem solving. Teachers who had less teaching experience thought of themselves as more capable, while teachers with more teaching experience demonstrated a lower level of self-perception in the four dimensions of digital competence; in the study of Martín, Usart and Carnicero [50] similar results regarding teaching experience were observed among Spanish teachers.

\section{Conclusions}

The findings of this study describe the self-perceptions of Chinese university teachers' digital competence, with particular attention given to gender and teaching experience. As for future lines of research, further study should be done to compare teachers' selfperceptions of their digital competence between group samples coming from western and eastern universities, and to explore the reasons why there are differences between male and female teachers in terms of self-perception of digital competence and what causes teachers with more years of teaching experience to perceive themselves as less competent in some areas. All component areas of college teachers' digital competence need to be investigated in depth in the future as diagnosing and promoting the development of digital competence has become one of the main challenges for schools today [52]. Moreover, it will be interesting to analyze the gap between teachers' self-perceptions and their actual digital competence. On the basis of these findings, teachers' digital competence could be assessed in a rather reasonable way and thus appropriate projects and programs could be launched to improve their competence accordingly, in an effort to meet the challenges and needs in the new age, and thus eventually to improve the quality of education.

There are several limitations to this study. First, the limitation of methodology; throughout this study we refer to teachers' self-perceptions rather than to real data about their level of digital competence, and the real state of teachers' digital competence may 
not be reflected. Second, the in-service teachers in this study are from one university but different faculties and their participation in completing the online questionnaire was voluntary, which could have influenced the sample size. Third, this study was particularly focused on gender and teaching experience; future research needs to be conducted so as to explore more factors that could affect digital competence. This study, was an initial step to explore the level of digital competence of college teachers; using correlation and regression analyses is recommended in future studies to show how the components of digital competence are related to each other.

Author Contributions: Conceptualization, Y.Z.; methodology, Y.Z., A.M.P.L. and M.C.S.G.; software, Y.Z.; validation, all authors; formal analysis, Y.Z.; resources, L.Z.; data curation, Y.Z.; writingoriginal draft preparation, Y.Z.; writing-review and editing, A.M.P.L., M.C.S.G. and L.Z.; visualization, Y.Z.; supervision, A.M.P.L. and M.C.S.G. All authors have read and agreed to the published version of the manuscript.

Funding: This research received no external funding.

Institutional Review Board Statement: Not applicable.

Informed Consent Statement: Informed consent was obtained from all subjects involved in the study.

Data Availability Statement: Not applicable.

Conflicts of Interest: The authors declare no conflict of interest.

\section{References}

1. Gillen, J. Digital Literacies; Routledge: London, UK, 2014.

2. Mezarina, C.; Paez, H.; Teran, O.; Toscano, R. Aplicacion de las TIC en la educacion superior como estrategia innovadora para el desarrollo de competencias digitales. Campus Virtuales 2015, 3, 88-101. Available online: http://uajournals.com/ojs/index.php/ campusvirtuales/article/view/52 (accessed on 12 December 2020).

3. Cabero-Almenara, J.; Barroso-Osuna, J.; Gutierrez-Castillo, J.J.; Palacios-Rodriguez, A. The teaching digital competence of health sciences teachers. A Study at Andalusian universities (Spain). Int. J. Environ. Res. Public Health 2021, 18, 2552. [CrossRef] [PubMed]

4. Portillo, J.; Garay, U.; Tejada, E.; Bilbao, N. Self-perception of the digital competence of educators during the COVID-19 pandemic: A cross-analysis of different educational stages. Sustainability 2020, 12, 128. [CrossRef]

5. Esteve-Mon, F.M.; Gisbert-Cervera, M.; Lázaro-Cantabrana, J.L. La competencia digital de los futuros docentes: ¿ como se ven los actuales estudiantes de educaciin? Perspect. Educ. Form. Profr. 2016, 55, 38-54.

6. Khvilon, E.; Patru, M.; UNESCO. Information and Communication Technologies in Teacher Education: A Planning Guide; Technology Pedagogy \& Education, Routledge: Oxfordshire, UK, 2002.

7. Fernandez, J.M.; Roman, P.; El Homrani, M. TIC y discapacidad. Conocimiento del profesorado de educacion primaria en Andalucoa. Aula Abierta 2017, 46, 65-72. [CrossRef]

8. Krumsvik, R.J. Teacher educators' digital competence. Scand. J. Educ. Res. 2014, 58, 269-280. [CrossRef]

9. Napal Fraile, M.; Peñalva-Vélez, A.; Mendióroz Lacambra, A.M. Development of digital competence in secondary education teachers' training. Educ. Sci. 2018, 8, 104. [CrossRef]

10. Silva, J.S.; Usart, M.U.; Lazaro-Cantabrana, J.L.L.C.; Silva, J.; Usart, M.; Lazaro-Cantabrana, J.L. Teacher's digital competence among final year pedagogy students in Chile and Uruguay. Comunicar. Media Educ. Res. J. 2019, 27, $33-43$.

11. Cabezas, M.; Casillas, S. Social educators: A study of digital competence from a gender differences perspective. Croat. J. Educ. 2018, 20, 1-32.

12. Garcia-Esteban, S. Do video learning objects develop digital competence in teacher training? Rev. Electr. Linguist. Apl. 2017, 16, 85-102.

13. Lista, E.A.G.J.; Sanchez-Torres, M.; Gonzalez-Zabala, M.P. Hacia un modelo de referencia de procesos de gestion del conocimiento para organizaciones desarrolladoras de software: Validacion por expertos. AD-Minister 2015, 26, 41-72.

14. Kim, H.J.; Hong, A.J.; Song, H.D. The relationships of family, perceived digital competence and attitude, and learning agility in sustainable student engagement in higher education. Sustainability 2018, 10, 4635. [CrossRef]

15. Jimenez-Cortes, R.; Vico-Bosch, A.; Rebollo-Catalan, A. Female university student's ICT learning strategies and their influence on digital competence. Int. J. Educ. Technol. High. Educ. 2017, 14, 10. [CrossRef]

16. Tammaro, R.; D'Alessio, A. Teacher training and digital competence: A pedagogical recommendation. Int. J. Digit. Lit. Digit. Competence 2016, 7, 1-10. [CrossRef]

17. European Commission. A Digital Agenda for Europe, 2010. Access to European Union Law Website. Available online: https: / / eur-lex.europa.eu/LexUriServ/LexUriServ.do?uri=COM:2010:0245:FIN:EN:PDF (accessed on 18 December 2020).

18. Ferrari, A. Digital Competence in Practice: An Analysis of Frameworks; JRC IPTS: Sevilla, Spain, 2012. [CrossRef] 
19. Janssen, J.; Stoyanov, S.; Ferrari, A.; Punie, Y.; Pannekeet, K.; Sloep, P. Experts' views on digital competence: Commonalities and differences. Comput. Educ. 2013, 68, 473-481. [CrossRef]

20. Carretero, S.; Vuorikari, R.; Punie, Y. The Digital Competence Framework for Citizens. Publications Office of the European Union. 2017. European Comission Website. Available online: https:/ / ec.europa.eu/jrc/en/publication/eur-scientific-and-technicalresearch-reports/digcomp-21-digital-competence-framework-citizens-eight-proficiency-levels-and-examples-use (accessed on 24 March 2021).

21. Ferrari, A. DIGCOMP: A Framework for Developing and Understanding Digital Competence in Europe. 2013. European Comission Website. Available online: https:/ / publications.jrc.ec.europa.eu/repository/bitstream/JRC83167/lb-na-26035-enn. pdf (accessed on 25 March 2021).

22. Vuorikari, R.; Punie, Y.; Gomez, S.C.; Van Den Brande, G. DigComp 2.0: The Digital Competence Framework for Citizens. Update Phase 1: The Conceptual Reference Model (No. JRC101254); Joint Research Centre: Seville, Spain, 2016.

23. Mishra, P.; Koehler, M.J. Technological pedagogical content knowledge: A framework for teacher knowledge. Teach. Coll. Rec. 2006, 108, 1017-1054. [CrossRef]

24. Krumsvik, R.J. Skulen og den Digitale Læringsrevolusjonen; Universitetsforlaget: Oslo, Norway, 2007.

25. Guillen-Gamez, F.D.; Mayorga-Fernandez, M.J. Quantitative-comparative research on digital competence in students, graduates and professors of faculty education: An analysis with ANOVA. Educ. Inf. Technol. 2020, 25, 4157-4174. [CrossRef]

26. Romero-Tena, R.; Barragan-Sanchez, R.; Llorente-Cejudo, C.; Palacios-Rodriguez, A. The challenge of initial training for early childhood teachers. A cross sectional study of their digital competences. Sustainability 2020, 12, 4782. [CrossRef]

27. Redecker, C. European Framework for the Digital Competence of Educators: DigCompEdu (No. JRC107466); Joint Research Centre: Seville, Spain, 2017.

28. Ryhta, I.; Elonen, I.; Saaranen, T.; Sormunen, M.; Mikkonen, K.; Kaariainen, M.; Salminen, L. Social and health care educators perceptions of competence in digital pedagogy: A qualitative descriptive study. Nurse Educ. Today 2020, 92, 104521. [CrossRef]

29. Ortega-Sanchez, D.; Gomez-Trigueros, I.M.; Trestini, M.; Perez-Gonzalez, C. Self-perception and training perceptions on teacher digital competence (TDC) in Spanish and French university students. Multimodal Technol. Interact. 2020, 4, 74. [CrossRef]

30. INTEF. Marco Comun de Competencia Digital Docente, 2017. INTEF Website. Available online: https://aprende.intef.es/sites/ default/files /2018-05/2017_1020_Marco-Com\%C3\%BAn-de-Competencia-Digital-Docente.pdf (accessed on 26 March 2021).

31. The General Office of the CPC Central Committee and the General Office of the State Council. China Education Modernization 2035, 2017. China State Council Website. Available online: http://www.gov.cn/zhengce/2019-02/23/content_5367987.html (accessed on 6 January 2021).

32. Ministry of Education of China. Education Informatization 2.0 Action Plan, 2018. Ministry of Education of China Website. Available online: http://www.moe.gov.cn/srcsite/A16/s3342/201804/t20180425_334188.html (accessed on 8 January 2021).

33. Huang, J. Interpretation of China's education modernization 2035 from the perspective of lifelong education. Rev. Educ. Res. 2020, $34,1-2$.

34. Zhu, Z.T. China Education Informationization Decade. J. China Educ. Technol. 2011, 1, 20-25.

35. Zhang, G.; Wang, Z. Play a leading role in supporting information technology to serve the overall development of education modernization-Study and understand the 13th Five-Year Plan of education informatization. China Educ. Technol. 2017, 2, 140-144.

36. Hernandez, R.; Fernandez, C.; Baptista, P. Metodología de la Investigacion; McGraw Hill: Santa Fe, Mexico, 2014.

37. Taquez, H.; Rengifo, D.; Mejia, D. Diseno de un instrumento para evaluar el nivel de uso y apropiacion de las TIC en una institucion de educacion superior, 2017. Reposital Website. Available online: https:/ /reposital.cuaieed.unam.mx:8443/xmlui/ handle/20.500.12579/5019 (accessed on 15 June 2019).

38. Lopez, J.; Pozo, S.; Fuentes, A. Analysis of electronic leadership and digital competence of teachers of educational cooperatives in Andalucia (Spain). Multidiscip. J. Educ. Res. 2019, 9, 194-223. [CrossRef]

39. Hatlevik, O.E.; Christophersen, K.-A. Digital competence at the beginning of upper secondary school: Identifying factors explaining digital inclusion. Comput. Educ. 2013, 63, 240-247. [CrossRef]

40. Escudero, V.G.; Gutierrez, R.C.; Somoza, J.A.G.-C. Analisis de la autopercepcion sobre el nivel de competencia digital docente en la formacion inicial de maestros/as. Rev. Electrónica Interuniv. Form. Profr. 2019, 22, 193-218.

41. Benali, M.; Kaddouri, M.; Azzimani, T. Digital competence of Moroccan teachers of English. Int. J. Educ. Dev. Using Inf. Commun. Technol. 2018, 14, 100-120. Available online: https://www.learntechlib.org/p/184691/ (accessed on 18 December 2020).

42. Fuentes, A.; Lopez, J.; Pozo, S. Analysis of the digital teaching competence: Key factor in the performance of active pedagogies with augmented reality. REICE 2019, 17, 27-42. [CrossRef]

43. Villarreal-Villa, S.; García-Guliany, J.; Hernandez-Palma, H.; Steffens-Sanabria, E. Competencias docentes y transformaciones en la educacion en la era digital. Form. Univ. 2019, 12, 3-14. Available online: https://scielo.conicyt.cl/scielo.php?pid=S0718-500620 19000600003\&script=sci_arttext\&tlng=e (accessed on 7 January 2021). [CrossRef]

44. Cabero, J.; Llorente, M.C.; Puentes, A. Alfabetizacion Digital: Un estudio en la Pontificia Universidad Catolica Madre y Maestra; Fortic: Sevilla, Spain, 2008.

45. Moreno-Guerrero, A.J.; Fernandez Mora, M.A.; Alonso Garcia, S. Influencia del genero en la competencia digital docente. Rev. Espac. 2019, 40, 30. 
46. Sanchez Prieto, J.; Trujillo Torres, J.M.; Gomez Garcia, M.; Gomez Garcoa, G. Gender and digital teaching competence in dual vocational education and training. Educ. Sci. 2020, 10, 84. [CrossRef]

47. García-González, I.; Gros, B.; Escofet, A. The influence of gender on digital culture of university students. Athenea Digit. 2012, 12, 95-114.

48. Almerich Cervero, G.; Suarez Rodriguez, J.M.; Jornet Melia, J.M.; Orellana Alonso, M.N. Las competencias y el uso de las tecnologias de informacion y comunicacion (TIC) por el profesorado: Estructura dimensional. Rev. Electron. Investig. Educ. 2011, $13,28-42$.

49. Martos, E.; Perez, P.; Bernal, J. Relaciin entre la edad del profesorado de musica andaluz y el desarrollo de la Escuela TIC 2.0. Rev. Complut. Educ. 2016, 27, 757-777.

50. Martin, R.F.P.; Usart, M.; Carnicero, M.J.U. La competencia digital de los docentes de los conservatorios. Estudio de autopercepcion en Espana. Rev. Electron. LEEME 2019, 44, 24-41. [CrossRef]

51. Sanchez, S.P.; Belmonte, J.L.; Cruz, M.F.; Antonio, J. Analisis correlacional de los factores incidentes en el nivel de competencia digital del profesorado. Rev. Electron. Interuniv. Form. Profr. 2020, 23, 143-149. Available online: https://revistas.um.es/reifop/ article/view/396741/278101 (accessed on 30 December 2020).

52. Tomczyk, L. Skills in the area of digital safety as a key component of digital literacy among teachers. Educ. Inf. Technol. 2020, 25, 471-486. [CrossRef] 